\title{
Óriási, a hátsó mediastinumot és a retroperitoneumot részben kitöltő schwannoma mütéti kezelése
}

\author{
Baranyai Zsolt dr. - Balázs Ákos dr. \\ Semmelweis Egyetem, Általános Orvostudományi Kar, I. Sebészeti Klinika, Budapest
}

\begin{abstract}
A mediastinum kórképeinek jellemzője, hogy az életfontosságú képletek anatómiai koncentrációja egyszerre jelent diagnosztikus és sebésztechnikai kihívást. Az itt jelentkező térfoglaló folyamatok növekedésük során hosszú ideig tünetszegények vagy tünetmentesek lehetnek, s ezért nemegyszer extrém méretet elérve kerülnek mútétre. Az 58 éves férfi beteg 15 éve ismert, légzési panaszokat okozó, a bal hátsó mediastinumban és retroperitoneumban lévő kiterjedt térfoglaló folyamat és mellkasi folyadékgyülem miatt került klinikánkra felvételre. A mellkasi fluidum citológiai vizsgálatával malignitást nem tudtunk igazolni. CT- és MR-vizsgálatokkal nem lehetett egyértelmúen eldönteni, hogy a folyamat a mediastinalis térből (Th. IX-X. csigolya területe) vagy a bal mellékveséből indult ki. Hormonális aktivitást nem észleltünk. Thoracolaparotomiából 20,2 × 11,1 × 10,8 cm átmérőjü, gerinceredetű tumort exstirpáltunk, rekeszrekonstrukciót végeztünk. A szövettani vizsgálat schwannomát igazolt. A hosszas kompresszió miatt komprimált bal tüdő a megszakított légzésrehabilitációs kezelés hatására csak részlegesen expandált. Az általában csak előrehaladott állapotban felismerésre kerülő, nagyméretú mediastinalis térfoglalásoknál, más terápiás modalitások hiányában, kizárólag mútéti megoldás eredményezhet gyógyulást. Ezek a mútétek csak multidiszciplináris összefogással, kellő jártassággal rendelkező központokban végezhetôk.
\end{abstract}

Orv Hetil. 2019; 160(37): 1476-1479.

Kulcsszavak: retroperitonealis schwannoma, esetismertetés

\section{Surgical excision of a giant schwannoma located in the posterior mediastinum and partially in the retroperitoneum}

A characteristics of mediastinal disorders is that the high anatomical density of vital structures in this region represents a challenge for diagnosis and surgical treatment. Space-occupying lesions can grow without causing overt manifestations - or can progress symptom-free - hence they can reach an extreme size by the time of surgery. A 58-year-old male patient was hospitalized for pleural effusion and an extensive, space-occupying mediastinal lesion, which had been causing respiratory symptoms for 15 years. Cytology of the pleural effusion did not confirm malignancy. The CT scan depicted progression manifested as an increase in the size of the lesion with a likely site of origin in the left adrenal gland. According to the MRI, by contrast, the lesion might have originated in the region of vertebrae $\mathrm{Th}_{9-10}$, as suggested by the lack of dural continuity. However, its adrenal origin could not be excluded either; endocrine activity was not detected. An operation was performed with a neurosurgeon included in the surgical team. A spinal tumor of the size of 20.2 by 11.1 by $10.8 \mathrm{~cm}$ was removed through thoraco-laparotomy, and reconstruction of the diaphragm was performed. Histology confirmed a schwannoma. Postoperatively, the expansion of the lung was only partial, because the patient discontinued respiratory rehabilitation. The follow-up CT scan depicted local recurrence. In the lack of alternative therapeutic modalities, surgical resection is usually the sole option for the management of large, mediastinal space-occupying lesions diagnosed at an advanced stage. Such operations should only be performed in specialist surgical centers and with multidisciplinary collaboration.

Keywords: retroperitoneal schwannoma, case report

Baranyai Zs, Balázs Á. [Surgical excision of a giant schwannoma located in the posterior mediastinum and partially in the retroperitoneum]. Orv Hetil. 2019; 160(37): 1476-1479.

(Beérkezett: 2019. március 30.; elfogadva: 2019. április 10.) 


\section{Rövidítések}

CT = (computed tomography) számítógépes tomográfia; MR $=($ magnetic resonance $)$ mágneses rezonancia $; \mathrm{MRI}=$ (magnet ic resonance imaging) mágnesesrezonancia-képalkotás; RTG = röntgen

A mediastinum kórképeinek jellemzője, hogy az életfontosságú képletek anatómiai koncentrációja egyszerre jelent diagnosztikus és sebésztechnikai kihívást. Az itt kialakuló tumorok többnyire hosszú ideig tünetszegények. A megjelenő tünetek többnyire az expanzív növekedés következtében a környezetre gyakorolt térszúkületből adódnak. Kompressziós tünetek alakulhatnak ki a légutak, a felső gastrointestinalis traktus, a mellkasi nagyerek, illetve a szív vonatkozásában. Dyspnoe, dysphagia, rekedtség, Horner-tünetegyüttes, vena cava superior szindróma, keringési elégtelenség képét észlelhetjük. A hátsó mediastinum primer tumorai 75\%-ban neurogén eredetú́ek [1]. Ritkán a hasüregi tumorok (gyomor, máj, vese stb.) rekeszen történó direkt terjedés során propagálnak a hátsó gátorüregbe. A mellékvese mellett elhelyezkedő schwannomákat könnyen óriási mellékvesetumorokkal lehet összetéveszteni. Néhány ilyen esetet közöltek az irodalomban [2,3].

\section{Esetismertetés}

Az 58 éves férfi beteg anamnézisében tonsillectomia, traumás végtagi fractura szerepelt. 2003-ban dyspnoe miatt történt kivizsgálás során észlelték a bal oldali mellkasfélben térfoglaló folyamat jelenlétét; a bronchoscopia carcinoid suspitiumát vetette fel. 2005-ben, majd 2012-ben további vizsgálatok, valamint pleuralis folyadék többszöri punkciója történt, melynek citológiai vizsgálata negatív eredményt adott. 2013 tavaszán a teriméből vastagtübiopszia készült, melynek eredménye krónikus pleuritist állapított meg. 2013 szeptemberében került klinikánkra a beteg sürgősségi beutalással, típusos duodenalis perforáció klinikai képével. A perforáció suturája történt. A mellüregi terime a tüdő 9-10. szegmentumának területét elfoglalva, a jelentős mennyiségű mellüregi folyadékkal együtt a bal oldali tüdőfél kompressziós atelectasiáját okozta (1.ábra). A mellkasi fluidum citológiai vizsgálatával malignitást nem tudtunk igazolni. Az elváltozásból vett biopszia vizsgálata nem adott egyértelmú diagnózist. CT-vizsgálat során a korábbi vizsgálatok leletein megadott méretekhez képest jelentős növekedés volt megállapítható. A 20,2 × 10,8 × 11,1 cm-es elváltozás diszlokálta a thoracalis aortát, az oesophagust, a rekeszizmot, a bal vesét. A retroperitoneum irányába való kiterjedése felvetette a mellékveséból való kiindulás lehetőségét is (2. ábra).

MR-vizsgálat a terime paravertebralis elhelyezkedése mellett, a környezetétól való éles elhatárolódását mutatta. A korábban elvégzett képalkotó vizsgálatokat megerősítve leírta a mellkasi szervek diszlokációit, valamint a

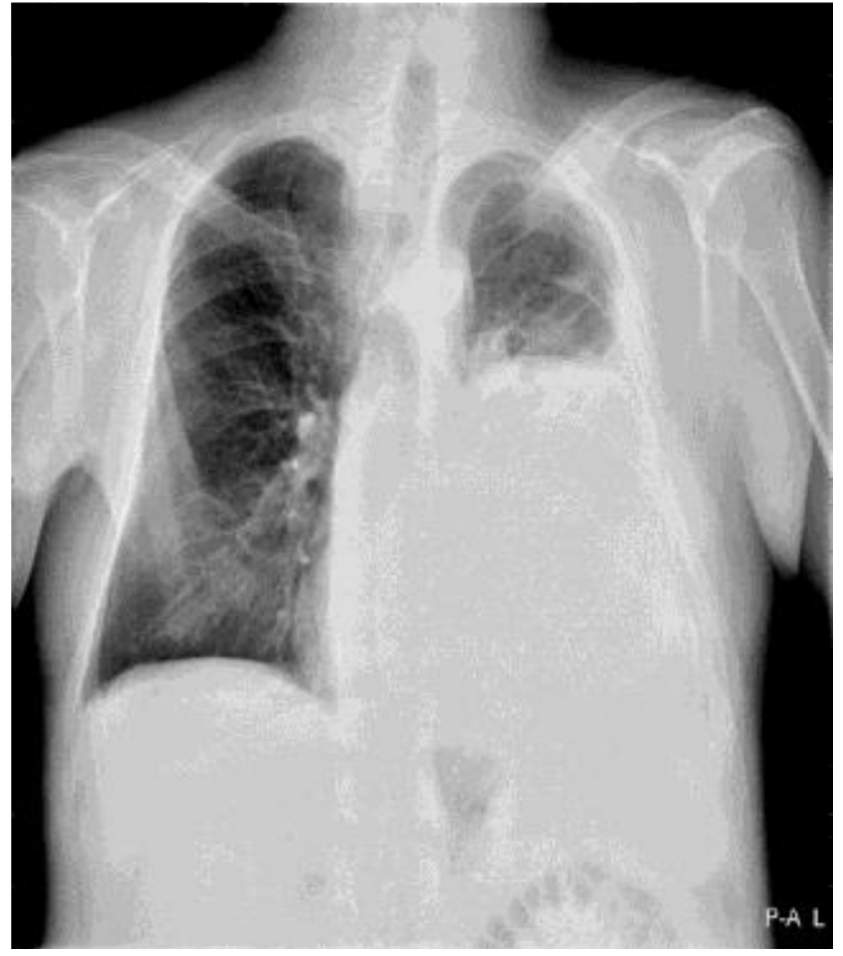

1. ábra

Mellkas-RTG-felvétel, melyen kiterjedt bal mellkasféli térfoglaló folyamat látható

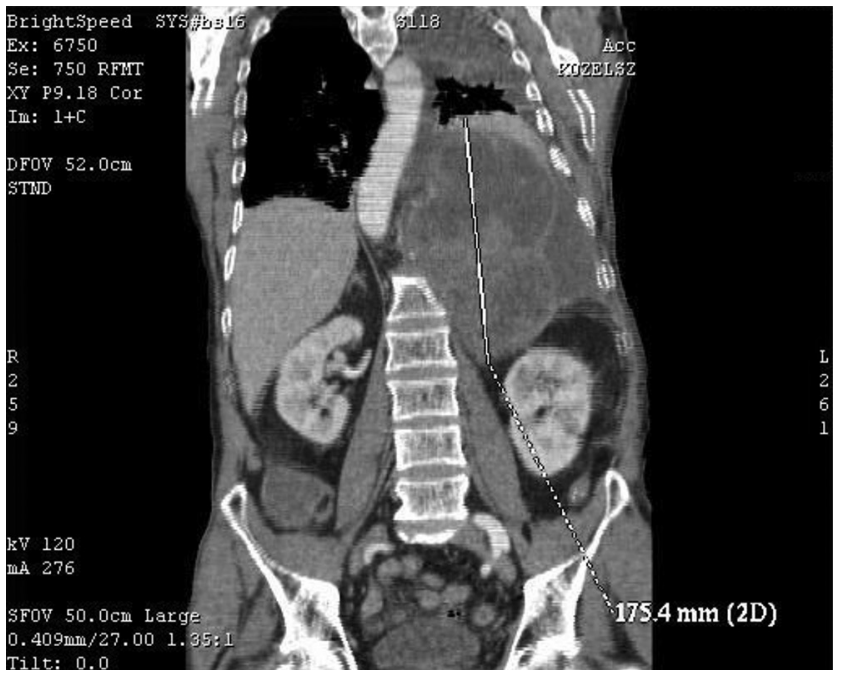

2. ábra

CT-felvétel. A korábbi dokumentációkkal összevetve a térfoglaló folyamat méretbeli progresszióját mutatta

pancreas test-farok és a vese diszlokációját. A folyamat kiindulását nem tudta biztonsággal megállapítani. A képalkotó vizsgálatokat együtt értékelve a thoracalis IX-X. csigolyák magasságában volt vélhető az elváltozás kiindulása, de mivel a bal mellékvese biztonsággal nem volt azonosítható, a bal mellékvesei eredet lehetősége is felmerült (3. ábra). A képalkotó eljárások alapján a terime szoros kontaktusban volt az aortával, az oesophagusszal, valamint a bal arteria és vena renalisszal. A pancreas testét és farkát ventralis, a bal vesét pedig caudalis irányban 


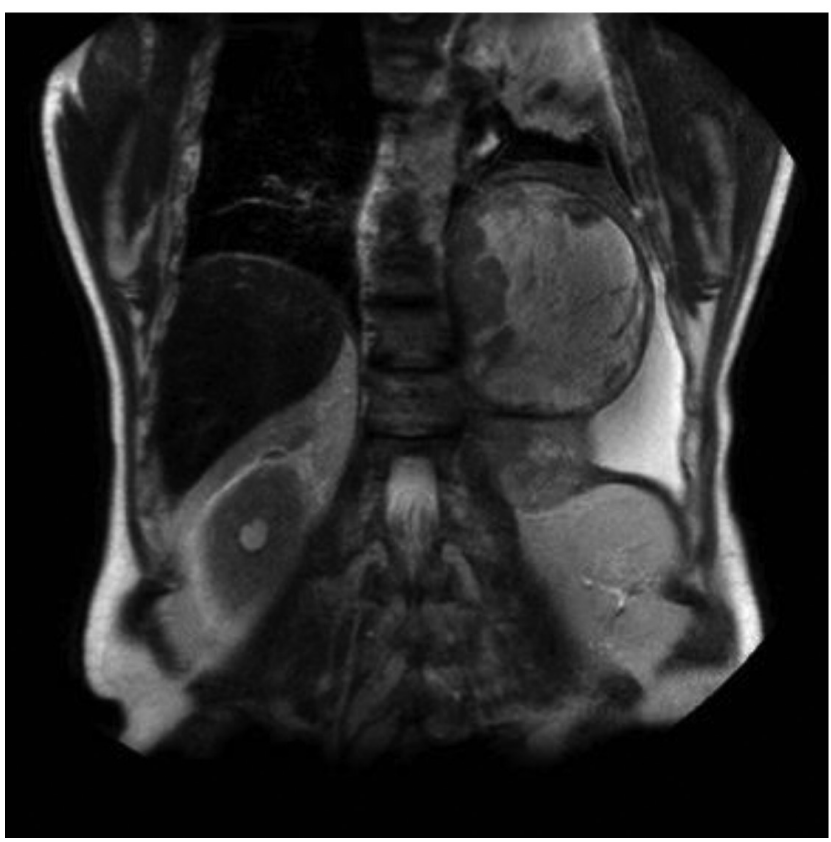

3. ábra

MR-vizsgálattal felvetődött, hogy a térfoglaló folyamat a Th. IX-X. csigolya területéról indul ki, mivel itt a dura folytonosságának hiányát igazolta, de a mellékvese-eredet sem volt kizárható

diszlokálta. A tumor kiindulását a vizsgálatok nem tudták egyértelmúen meghatározni, ám mivel az ábrázolódott felvételeken észleltük a rekesz caudalis irányban történő diszlokációját, az elváltozást mellkasi kiindulásúnak gondoltuk.

$\mathrm{Az}$ endokrinológiai konzílium hormonális aktivitást nem igazolt. A jelentősen atelectasiás bal tüdő gyakorlatilag nem vett részt a légzésben, így mütét előtt légzésfunkció-vizsgálatot, bronchoscopiát nem végeztünk.

A mútétet idegsebész bevonásával két, gasztroenterológiai sebészetben is jártas mellkassebész hajtotta végre. Az explorációt thoracolaparotomiából végeztük. A makroszkóposan malignusnak imponáló elváltozás szívósan kitapadt a rekeszhez, körben a mellüreg falához, ahonnan hosszas adhaesiolysissel tudtuk leválasztani. Ezzel szemben a pericardiumról könnyen le lehetett preparálni a tumort. Szintén hosszas adhaesiolysisre kényszerülve tudtuk szabaddá tenni a bal vesét, lépet és a gyomrot. Az elváltozás tumorosan rögzült a gerinc Th. IX-X. magasságában a csigolyákhoz, ahonnan élesen választottuk le (4. ábra). A tumor exstirpációja után a rekeszt öltéssorokkal rekonstruáltuk. A zsugorodott bal tüdő női ökölnyi nagyságú volt, vastag callus borította.

A beavatkozás során az alsó tüdőlebenyből kis légáteresztést kaptunk, melyet öltéssel láttunk el. A több mint egy évtizedig kompresszióban levő tüdő expanziója kérdéses volt, azonban a funkcióját vesztett bal tüdő eltávolítása túlságosan megterhelte volna a beteget, így a pulmonectomiától elálltunk.

A szövettani vizsgálat degeneratiós jeleket mutató cellularis schwannomát igazolt (5. ábra). A mütét utáni

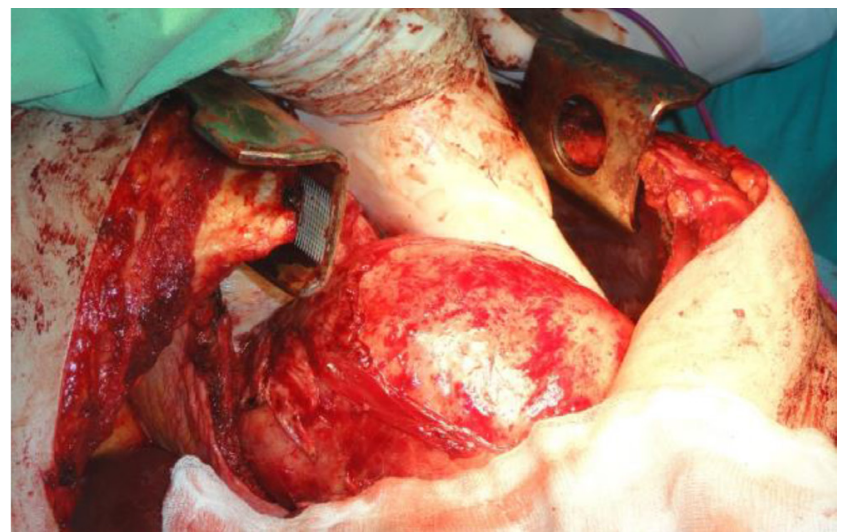

4. ábra

Mútéti kép (thoracolaparotomiából feltárt terület, a tumor rész ben felszabadítva)

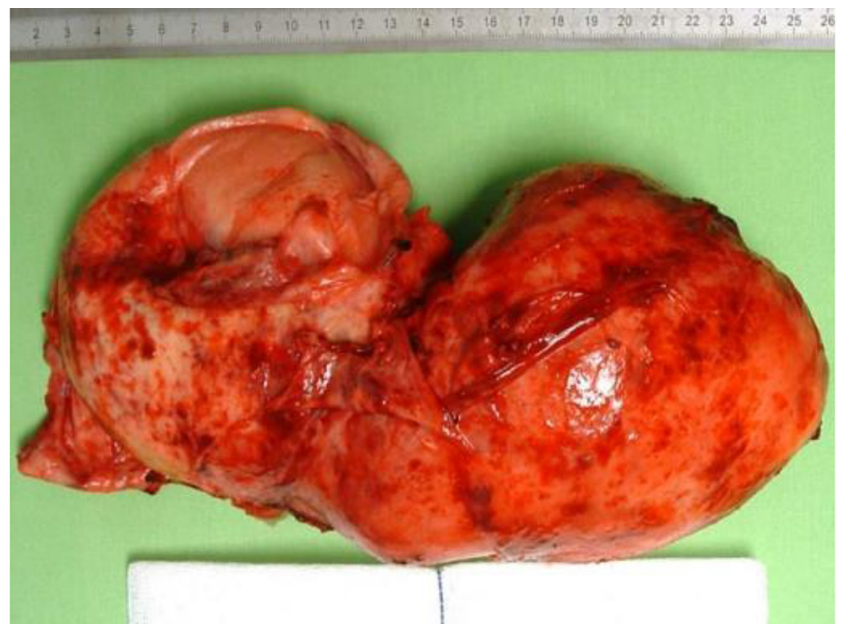

5. ábra

| Mütéti reszekátum

szak zavartalan volt. A pácienst légzésrehabilitációs osztályra helyeztük, a kezelés hatására a bal tüdő részlegesen expandált. A beteg azonban a megkezdett rehabilitációs kezelést önkényesen megszakította. Ismételten kialakult dyspnoe miatt került egy éve vizsgálatokra. Mellkasi CTvizsgálattal a nyaki-háti átmenetben $40 \mathrm{~mm}$ átmérőjű lágyrész-képletet észleltek. A bal tüdő kismértékben expandált, közte és a rekesz között fibroticus kötegek ábrázolódtak. A mellüri folyadék citológiai vizsgálata schwannomát igazolt. A beteg ismételten önkényesen megszakította a kezelést, jelenleg lényeges panasz nélkül otthonában él.

\section{Megbeszélés}

A schwannoma az esetek döntő többségében benignus, lassú növekedést mutató tumor, a növekedési periódus évekre tehető. A betegek többnyire sokáig tünetmentesek. A mediastinalis, retroperitonealis és sacralis elhelyezkedésû́ esetek nagy kiterjedésû́ek, és általában a tumor által okozott térfoglalás hívhatja fel a figyelmet a folyamatra $[4,5]$. Tünetmentességük miatt a leggyakrabban 
szürővizsgálat során végzett mellkas-RTG-felvételen kerülnek felfedezésre. A rosszindulatú schwannomák ritka daganatok. Az esetek több mint felében a von Recklinghausen-kórhoz kötődnek [6]. A mediastinalis schwannomák preoperatív diagnózisa nehézkes. Ki kell zárni az egyéb olyan betegségeket, amelyek érinthetik a gerincvelő mûködését. Ilyenek például: csontsérülések, elégtelen gerincvelöi vérellátás, csigolyatörés és porckorongsérv, valamint más jellegú kórképek, mint például szifilisz, vírusfertőzések, sclerosis multiplex és amyotrophiás lateralsclerosis. Feltétlenül fontos preoperatívan tisztázni, hogy a mediastinalis tumor nem aortaaneurysma, megaoesophagus vagy lymphoreticularis tumor-e. Többféle eljárást alkalmaznak a gerincvelői tumorok diagnosztizálására. Bár a gerincröntgen a csontelváltozásokat ábrázolhatja, a csontot még nem érintő tumorokat rendszerint nem mutatja ki. A kiterjedési és a környezethez való viszony tisztázására a CT-vizsgálat, míg a gerincvelő és a gerincoszlop egészének vizsgálatára az MRI tekinthető a legjobb eljárásnak. A teljes körű kivizsgálás részeként bronchoscopia, mediastinoscopia és a szövettani vagy citológiai mintavétel szükségessége merül fel. A schwannomák kezelése a radikális sebészi eltávolítás, ugyanis ezek a tumorok nem érzékenyek radio- vagy kemoterápiára. A rosszindulatú formák kiújulása ritka (5-10\%) $[7,8]$.

Saját betegünk komoly diagnosztikai probléma elé állított bennünket. Kivizsgálása, elsősorban alacsony compliance-e miatt, csak részleges és tájékoztató jellegü volt. Mütétre jelentős állapotrosszabbodása miatt kényszerültünk. A semiurgens preoperatív vizsgálatokkal a folyamat jellegét, a szövettani verifikálást egyértelmúen nem tudtuk megállapítani. Sem a CT-, sem az MR-vizsgálat nem tudott megbízhatóan különbséget tenni a tumor jóindulatú és rosszindulatú természete között. A hátsó mediastinalis tumorok preoperatív túbiopsziája gyakran nem tud végleges szövettani besorolást adni. Továbbá a szövettani típus jóindulatú jellege nem befolyásolja a klinikai kezelést. A progrediáló, hátsó mediastinalis tumor önmagában elegendő indikáció a sebészeti beavatkozáshoz. A mútét előtti képalkotó vizsgálatoknál elengedhetetlen a daganat anatómiai elemzése, kiemelt figyelemmel a létfontoságú mediastinalis környező struktúrákkal való kapcsolatokra. A multimodális képalkotásnak hangsúlyozottan választ kell adnia a tumor vascularis anatómiájára, a sebésznek ugyanis tisztában kell lennie az abnormális vérellátással.

A megfelelő sebészeti feltárás kiválasztása feltétele a sikeres mütéti kezelésnek és a szövődménylehetőség csökkentésének. A behatolás módját alapvetően a tumor lokalizációja határozza meg. Az exstirpatio elvégezhető thoracoscoposan vagy nyílt mútéttel, az eredmények közel hasonlóak. Nagyobb méretú $(>5 \mathrm{~cm})$ tumoroknál azonban a thoracoscopia háttérbe szorul [9-11]. Esetünkben az alkalmazott sebésztechnikai eljárás a thoracolaparotomia volt. Ezzel a behatolással a két testüreget érintő elváltozást biztonsággal tudtuk operálni.

Esetünkben a gondos tervezés, a multidiszciplináris együttmúködés sikerre vezetett. Ezeknek a tumoroknak az eltávolítása kihívást jelent, mely kellő jártassággal rendelkező központokban végzendő.

Anyagi támogatás: A közlemény megírása anyagi támogatásban nem részesült.

Szerzői munkamegosztás: B. Zs.: Szakirodalmi keresés, a kézirat megszövegezése. B. Á.: Szakmai ellenőrzés. A cikk végleges változatát mindkét szerző elolvasta és jóváhagyta.

Érdekeltségek: A szerzőknek nincsenek érdekeltségeik.

\section{Irodalom}

[1] Davidson KG, Walbaum PR, McCormack RJ. Intrathoracic neural tumours. Thorax 1978; 33: 359-367.

[2] Abdessater M, Mokdad ME, Gas J, et al. Juxta-adrenal schwannoma presenting as a giant adrenal tumor: a case report and a literature review. Int J Surg Case Rep. 2018; 53: 132-136.

[3] Damodaran S, Mahimairaj G, Velaichamy K. A case series of two cases of juxta-adrenal schwannoma presenting as adrenal mass lesion and review of the literature. Urol Ann. 2015; 7: 254-258.

[4] Goh BK, Tan YM, Chung YF, et al. Retroperitoneal schwannoma. Am J Surg. 2006; 192: 14-18.

[5] Song JY, Kim SY, Park EG, et al. Schwannoma in the retroperitoneum. J Obstet Gynaecol Res. 2007; 33: 371-375.

[6] Sharma SK, Koleski FC, Husain AN, et al. Retroperitoneal schwannoma mimicking an adrenal lesion. World J Urol. 2002; 20: 232-233.

[7] $\mathrm{Fu} \mathrm{H}, \mathrm{Lu} \mathrm{B}$. Giant retroperitoneal schwannoma: a case report. Int J Clin Exp Med. 2015; 8: 11598-11601.

[8] Vijayan SK, Shetty S, Bhat SR, et al. Retroperitoneal schwannoma: an atypical presentation. J Clin Diagn Res. 2014; 8: ND22ND23.

[9] Li Q, Gao C, Juzi JT, et al. Analysis of 82 cases of retroperitoneal schwannoma. ANZ J Surg. 2007; 77: 237-240.

[10] Yamaguchi M, Yoshino I, Fukuyama S, et al. Surgical treatment of neurogenic tumors of the chest. Ann Thorac Cardiovasc Surg. 2004; 10: 148-151.

[11] Han PP, Dickman CA. Thoracoscopic resection of thoracic neurogenic tumors. J Neurosurg. 2002; 96(3 Suppl): 304-308.

(Baranyai Zsolt dr., Budapest, Üllői út 78., 1082) e-mail: barazso@gmail.com)

A cikk a Creative Commons Attribution 4.0 International License (https://creativecommons.org/licenses/by/4.0/) feltételei szerint publikált Open Access közlemény, melynek szellemében a cikk bármilyen médiumban szabadon felhasználható, megosztható és újraközölhető, feltéve, hogy az eredeti szerző és a közlés helye, illetve a CC License linkje és az esetlegesen végrehajtott módosítások feltüntetésre kerülnek. (SID_1) 